\title{
CYTOTOXICITY OF SUBFRACTIONS AND COMPOUNDS FROM POLYMNIA SONCHIFOLIA
}

\author{
Maria Judite B. Fernandes ${ }^{1 *}$; Caroline Limas ${ }^{1}$; Maria Helena Rossi ${ }^{1}$; Edlayne Gonçales ${ }^{1}$; Isabela C. Simoni ${ }^{1}$ \\ ${ }^{1}$ Instituto Biológico, Centro de P\&D de Sanidade Animal, São Paulo, SP, Brasil
}

Submitted: May 04, 2005; Returned to authors for corrections: October 06, 2005; Approved: November 22, 2005

\begin{abstract}
Our previous works showed that extracts and fractions from Polymnia sonchifolia had presented an inhibitory activity on growth and aflatoxin production by Aspergillus flavus in non-cytotoxic concentrations. In this work, report results on the in vitro cytotoxicity of subfractions and of a mixture of sesquiterpenes lactones from Polymnia sonchifolia on Vero cells. The cytotoxicity was assayed through crystal violet staining (CVS) method and the 50\% inhibitory concentration for cell growth (IC50) was calculated. Both subfractions and the mixture of sesquiterpenes lactones did not show in vitro cytotoxicity to Vero cells on active biologically concentrations against production of aflatoxin B1 by Aspergillus flavus.
\end{abstract}

Key words: Polymnia sonchifolia, subfractions, lactones, cytotoxicity, crystal violet staining (CVS) method

\section{INTRODUCTION}

The use of natural products for curative and therapeutic purposes is of long date. However, the potential use of higher plants as sources of new drugs is still poorly explored. In last decades, there has been growing interest in the use of natural products, especially those derived from plants, as one alternative method at the conventional chemical control $(2,11)$.

The contamination of foods with aflatoxin B1 produced by Aspergillus flavus has caused serious problems to animal and human health. Extracts of certain plants are toxic to fungi and may be useful in controlling the fungal growth and/or aflatoxin production. Our previous studies reported that extracts and fractions from Polymnia sonchifolia in Aspergillus flavus culture presented inhibitory activity against aflatoxin production $(3,10)$.

However, the safety of any therapeutic agent is of paramount importance and appropriate toxicity assays to ensure biological safety of biomaterials should always be carried out. The bioassays can use inferior organisms (microorganism, mollusks), biochemical assays (enzymes, receptors), cell cultures (animal and human), isolated organs and in vivo assays (mammals, amphibians, birds) (8,11). In vitro cytotoxicity assays with cultured cells are very common because they are rapid, inexpensive and do not have ethical implications $(4,5,12)$. Several methods for determining cellular viability and/or growth following in vitro exposure to compounds have been reported. These methods use well know dyes that develop a color, allowing a colorimetric measurement of cell viability $(1,5,8,12)$. The crystal violet staining method (CVS) is one of these methods, and measures the effects of compounds on cell growth through colorimetric evaluation of fixed cells stained with crystal violet $(7,12)$.

The aim of present work was to continue the bioactivityguided fractionation from Polymnia sonchifolia with the study of cytotoxicity of its subfractions and pure compound through CVS method.

\section{MATERIALS AND METHODS}

\section{Plant}

Leaves from Polymnia sonchifolia were collected in Capão Bonito city, São Paulo state, Brazil. The dried and powdered leaves were submitted to extraction with ethanol $98 \%$ (three

*Corresponding Author. Mailing address: Instituto Biológico, Centro de P \& D de Sanidade Animal. Av. Conselheiro Rodrigues Alves, 1252. 04014-002, São Paulo, SP, Brasil. Telefax: (+5511) 5087-1714. E-mail: judite@biologico.sp.gov.br 
times) at room temperature. The solvent was evaporated under vacuum yielding ethanolic extract $(\mathrm{EE})$. The $\mathrm{EE}$ was submitted to flash CC over Silica-gel Column eluted with hexane, chloroform, ethyl acetate and methanol, resulting in the respective fractions (3). The methanolic fraction was submitted to a chromatographic column over Diaon HP-20 yielding the aqueous, methanol-water and $100 \%$ methanol subfractions. The ethyl acetate fraction was submitted to the chromatographic column over silica gel $60 \mathrm{H}$ eluted with hexane:acetate $(3: 7,2: 8$, $1: 9$ and $0: 10)$ and acetate:methanol (1:1 and 0:10) to yield the respective subfractions. The hexane:acetate (3:7) subfraction was submitted to the isolation of the constituents by chromatographic column on silica gel $60 \mathrm{H}$ and sephadex LH-20. The compounds isolated were identified using techniques of the ${ }^{13} \mathrm{C}$ and ${ }^{1} \mathrm{H}$ NMR (HMQC, HMBC, DEPT, NOISE, $\mathrm{H}^{1}-{ }^{1} \mathrm{H}$ COSY)(9).

\section{Preparation of plant material}

The hexane:acetate (3:7) and acetate:methanol (1:1) subfractions of ethyl acetate fraction; the aqueous, methanolwater and $100 \%$ methanol subfractions of methanolic fraction; and a mixture of two very similar lactones, enhydrin and uvedalin, were used in cytotoxicity assays. They were dissolved in ethanol (5\%), followed by addition of equal parts of sterile distilled water and Eagle's minimum essential medium (MEM), $2 \mathrm{x}$ concentrated, reaching a final concentration of $2,000 \mu \mathrm{g} / \mathrm{mL}$. All materials were filtered through a $0.22 \mu \mathrm{m}$ Millipore membrane, separated in aliquots and stored at $-20^{\circ} \mathrm{C}$.

\section{Cell culture}

Vero cell line (monkey kidney) was grown in MEM supplemented with $10 \%$ fetal bovine serum (FCS).

\section{Cytotoxicity assay}

The cytotoxicity was evaluated by the crystal violet staining (CVS) method described by Saotome et al. (12) and modified by Itagaki et al. (7). Briefly, in a 96-well tissue culture microplate (column 1 to 12) containing $0.1 \mathrm{~mL}$ of MEM in each well, $0.1 \mathrm{~mL}$ of the extract was inoculated in column 1 . The content of column 1 was two-fold serial diluted until column 6 . Subsequently, the wells from columns 1 to 8 were seeded with $0.1 \mathrm{~mL}$ of $10 \%$ MEM containing $3.0 \times 10^{4}$ Vero cells. Two-fold serial cell dilutions were made from columns 8 to 11 . The microplate was incubated for $72 \mathrm{~h}$ at $37^{\circ} \mathrm{C}$ in $5 \% \mathrm{CO}_{2}$ atmosphere. After this period, the medium was removed and the cells were stained with $0.4 \%$ crystal violet solution in methanol for $30 \mathrm{~min}$ and carefully washed with distilled water. The quantitative analysis (colorimetric evaluation of fixed cells) was performed by absorbance measurements in an automatic microplate reader at $595 \mathrm{~nm}$. The effect on cell growth was calculated as the difference in absorbance percentage in presence and absence of the plant material and illustrated in a dose-response curve. The concentration at which the growth of cells was inhibited to $50 \%$ of the control $\left(\mathrm{IC}_{50}\right)$ was obtained from this dose-response curve. Test of cytotoxicity of solvent (ethanol) was also included. For this, the Vero cells were treated with ethanol dilutions from 5 to $0.16 \%$. The experiments were repeated three times.

\section{RESULTS AND DISCUSSION}

The behavior of all three subfractions from the methanolic fraction was similar to that reported for the original fraction (3). The inhibition of growth of Vero cells was dose-dependent and only an exposition to $1000 \mu \mathrm{g} / \mathrm{mL}$ caused complete suppression of the cell growth. The dose-response curves of the three subfractions are shown in Fig. 1. The concentration at which the growth of cells was inhibited to $50 \%$ of the control $\left(\mathrm{IC}_{50}\right)$ was $584.43 \mu \mathrm{g} / \mathrm{mL} \pm 15.68,479.08 \mu \mathrm{g} / \mathrm{mL} \pm 25.64$ and $431.41 \mu \mathrm{g} /$ $\mathrm{mL} \pm 9.19$, respectively, for aqueous, methanol-water and $100 \%$ methanol subfractions.

Fig. 2 shows the effect of the two subfractions of the ethyl acetate fraction on cell growth after $72 \mathrm{~h}$. The number of viable cells decreased with concentration of the subfractions. The hexane:acetate subfraction presented analogous suppression of growth as the original fraction (3). It presented a accentuated inhibition of cell growth at $125 \mu \mathrm{g} / \mathrm{mL}$ and total inhibition at 250 $\mu \mathrm{g} / \mathrm{mL}$. On the other hand, the behavior of the acetate:methanol subfraction was similar to that of the subfractions from the

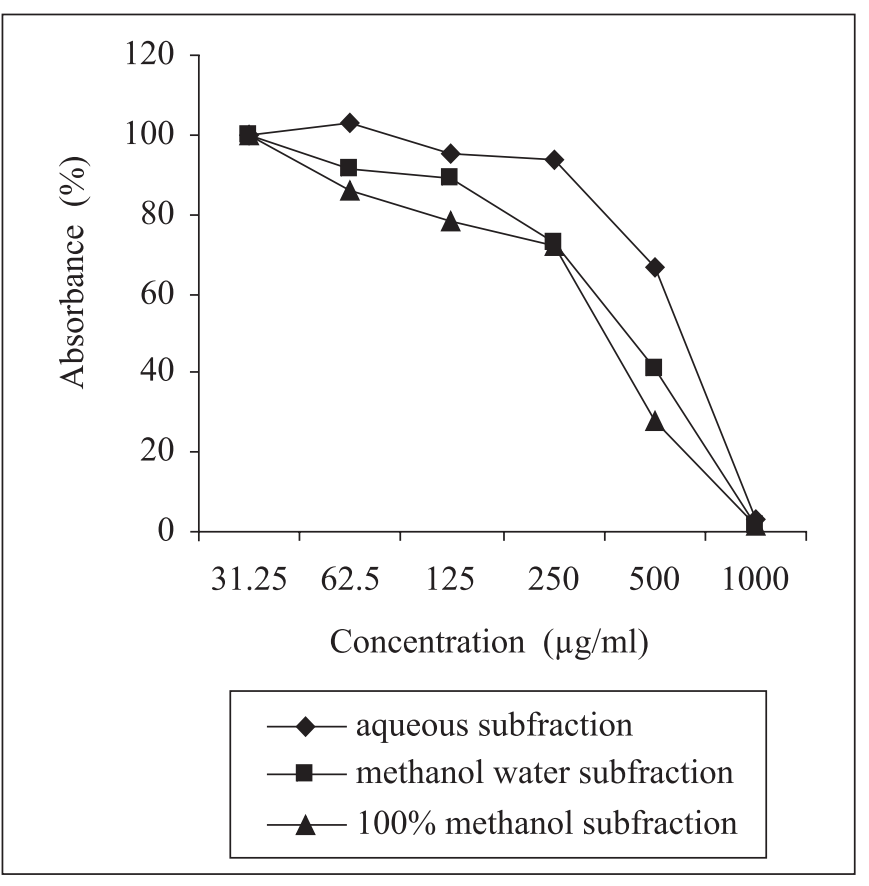

Figure 1. Dose-response curves of subfractions from methanolic fraction. 
methanolic fraction. The acetate:methanol subfraction caused complete suppression of the cell growth only at $1000 \mu \mathrm{g} / \mathrm{mL}$. The values of $\mathrm{IC}_{50}$ and the standard deviation were $106.05 \mu \mathrm{g} /$ $\mathrm{mL} \pm 2.19$ and $571.12 \mu \mathrm{g} / \mathrm{mL} \pm 13.35$, respectively, for hexane:acetate and acetate:methanol subfractions.

The mixture of the lactones, enhydrin and uvedalin, exhibited cytotoxicity similar to the hexane:acetate original subfraction (Fig. 2), causing a pronounced fall on cell growth at low concentration $(62.5 \mu \mathrm{g} / \mathrm{mL})$. The value of $\mathrm{IC}_{50}$ and the standard deviation were $87.71 \mu \mathrm{g} / \mathrm{mL} \pm 27.10$.

Fig. 3 shows the effect of ethanol on cell growth. This test was done to verify a possible cell toxicity caused by the solvent and production of false results. All dilutions were practically non toxic and the value of $\mathrm{IC}_{50}$ was $13 \%$. These results indicate

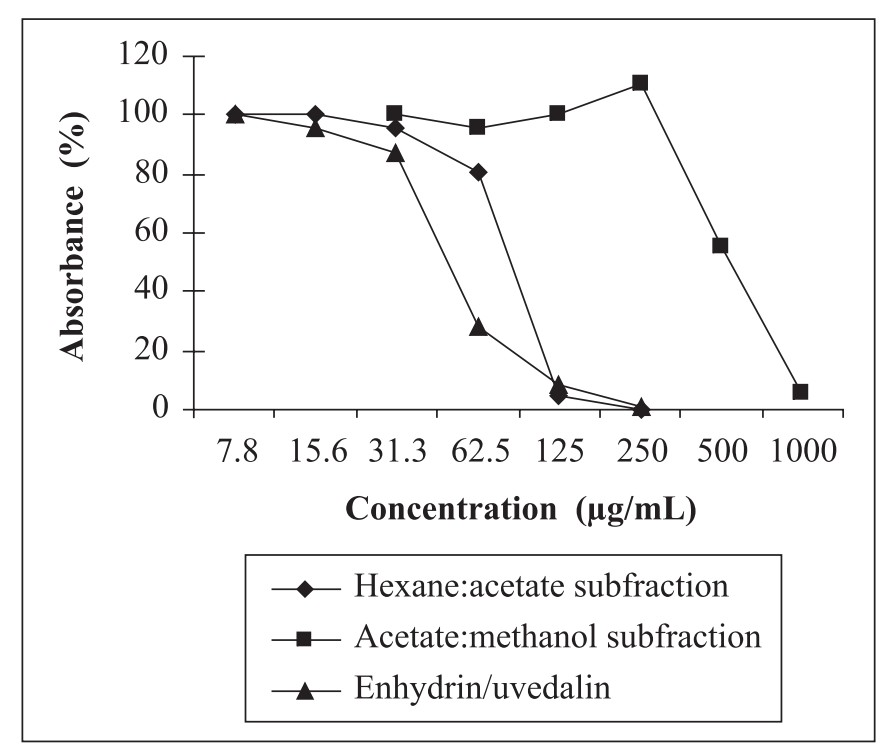

Figure 2. Dose-response curves of subfractions from ethyl acetate fraction.

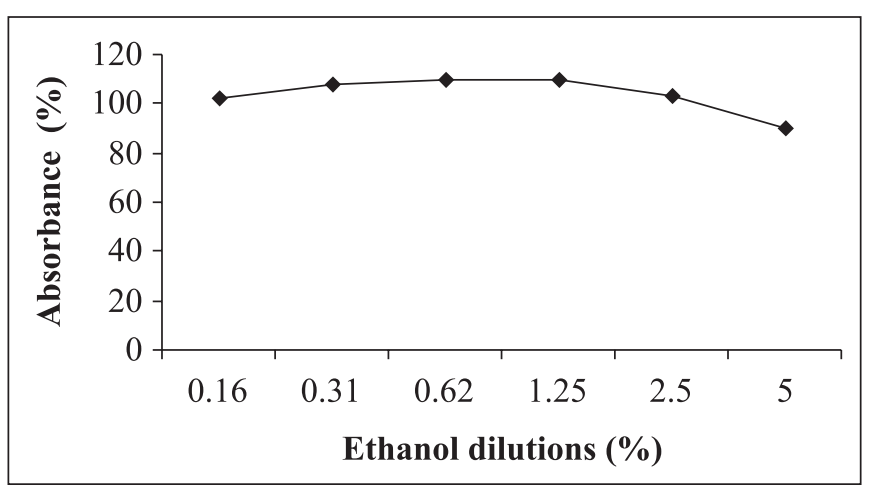

Figure 3. Dose-response curve of ethanol (solvent). that the remaining solvent in the cytotoxicity assays did not interfere in the results.

The in vitro cytotoxicity assays are used as screening tests before evaluation of material biocompatibility $(4,6)$. Cytotoxicity assays should be quantitative to allow for a ranking of material toxicity (1). Smee et al. (13) and Tani et al. (14) compared different methods for measuring the cytotoxicity of compounds including CVS method and obtained comparable results in terms of quantifying toxicity. Each method has specific advantages, disadvantages and limitations and the appropriate method is the user's choice. The CVS method is very effective because it is quite easy and reproducible and a number of materials can be evaluated simultaneously (7).

The concentrations of the subfractions and of the mixture of lactones from Polymnia sonchifolia $(20 \mu \mathrm{g} / \mathrm{mL})$ that inhibited aflatoxin production and Aspergillus flavus growth remained below the respective $\mathrm{IC}_{50}(9)$. These results encourage future studies, such as field applications of these materials as antifungal alternative controls, without toxicity.

\section{ACKNOWLEDGEMENTS}

The authors are grateful to the Fundação de Amparo à Pesquisa do Estado de São Paulo (FAPESP) for supporting the research, and to the Conselho Nacional de Desenvolvimento Científico e Tecnológico (PIBIC-CNPq) for the grant to Caroline Limas.

\section{RESUMO}

\section{Citotoxicidade de subfrações e lactonas de Polymnia sonchifolia}

Extratos e frações de Polymnia sonchifolia apresentaram em estudos preliminares uma atividade inibidora na produção de aflatoxinas e no crescimento de Aspergillus flavus. No presente trabalho foi avaliada a citotoxicidade das subfrações e de uma mistura de lactonas sesquiterpênicas de Polymnia sonchifolia pelo método de coloração pelo violeta cristal (CVS) em células Vero. A concentração que inibe o crescimento celular em 50\% $\left(\mathrm{IC}_{50}\right)$ foi determinada. Não foi observada nenhuma citotoxicidade para as células Vero nas concentrações biologicamente ativas contra a produção de aflatoxina pelo Aspergillus flavus.

Palavras-chave: Polymnia sonchifolia, subfrações, lactonas, citotoxicidade, método de coloração violeta cristal (CVS)

\section{REFERENCES}

1. Ciapetti, G.; Granchi, D.; Verri, E.; Savarino, L.; Cavedagna, D. Application of a combination of neutral red and amido black staining for rapid, reliable cytotoxicity testing of biomaterials. Biomaterials, 17, 1259-1264, 1996. 
2. Devienne K.F.; Raddi, M.S.G.; Pozetti, G.L. Das plantas medicinais aos fitofármacos. Rev. Bras. Pl. Med., 6(3), 11-24, 2004.

3. Gonçalez, E.; Felício, J.D.; Pinto, M.M.; Rossi, M.H.; Medina, C.S.; Fernandes, M.J.B.; Simoni, I.C. Inhibition of aflatoxin production by Polymnia sonchifolia and its in vitro cytotoxicity. Arq. Inst. Biol., 70(2), 159-163, 2003.

4. Harbell, J.W.; Knootz, S.W.; Lewis, R. W.; Lovell, D. IRAG working group: Cell cytotoxic assays. Food Chem. Toxicol., 35, 79-126, 1997.

5. Ishiyama, M.; Tominaga, H.; Shiga, M. Sasamoto, K. A combined assay of cell viability and in vitro cytotoxicity with a highly watersoluble tetrazolium salt, neutral red and crystal violet. Biol. Pharm. Bull., 19(11), 1518-1520, 1996.

6. ISO document 10993, Biological compatibility of medical devices Part 5: Tests for cytotoxicity: in vitro methods, 1992.

7. Itagaki, H.; Hagino, S.; Kato, S.; Kobayashi, T.; Umeda, M. An in vitro alternative to the draize eye-irritation test: evaluation of the crystal violet staining method. Toxicol. In Vitro, 5, 139-143, 1991.

8. Maciel, M.A. M.; Pinto, A.C.; Veiga Jr., V.F. Plantas medicinais: a necessidade de estudos multidisciplinares. Quim. Nova, 25(3), 429$438,2002$.
9. Pak, A. Polymnia sonchifolia: Fitoquímica e avaliação do crescimento e na produção de aflatoxinas por Aspergillus flavus, São Paulo, 2002, 100p. (M. Thesis. Instituto de Química de Araraquara. UNESP)

10. Pinto, M.M.; Gonçalez, E.; Rossi, M.H.; Felício, J.D.; Medina, C.S.; Fernandes, M.J.B.; Simoni, I.C. Activity of the aqueous extract from Polymnia sonchifolia leaves on growth and production of aflatoxin B1 by Aspergillus flavus. Braz. J. Microbiol., 32, 127-1279, 2001.

11. Rates, S.M.K. Plants as source of drugs Toxicon, 39, 603-613, 2001

12. Saotome, K.; Morita, H.; Umeda, M. Cytotoxicity test with simplified crystal violet staining method using microtitre plates and its application to injection drugs. Toxic in vitro, 3(4), 317-321, 1989.

13. Smee, D.F.; Morrison, A.C.; Barnard, D.L.; Sidwell, R.W. Comparison of colorimetric, fluorometric, and visual methods for determining anti-influenza ( $\mathrm{H} 1 \mathrm{~N} 1$ and $\mathrm{H} 3 \mathrm{~N} 2)$ virus activities and toxicities of compounds. J. Virol. Methods, 106, 71-79, 2002.

14. Tani, N.; Kinoshita, S.; Okamoto, Y.; Kotani, M.; Itagaki, H.; Murakami, N.; Sugiura, S.; Usami, M.; Kato, K.; Kojima, H.; Ohno, T.; Saijo, K.; Kato, M.; Hayashi, M.; Ohno, Y. Interlaboratory validation of the in vitro eye irritation tests for cosmetic ingredients. (8) Evaluation of cytotoxicity tests on SIRC cells. Toxic. in vitro, 13, 175-87, 1999. 